\title{
Insecticidal activity of essential oil from Eucalyptus globulus against Aphis nerii (Boyer) and Gynaikothrips ficorum (Marchal)
}

\author{
Russo, S., Yaber Grass, M. A., Fontana, H. C. and Leonelli, E.
}

\begin{abstract}
SUMMARY
Aphids and thrips are very important pest species of many greenhouse and field plants in the world. In recent years, there have been attempts to identify plants for their insecticidal property with a view to find out suitable alternatives to the indiscriminate use of chemical pesticides, which are a risk for human health and the environment. The aim of this work was to evaluate the insecticidal effect of Eucalyptus globulus Labill essential oil (EO) against Aphis nerii Boyer de Fonscolombe (Hemiptera: Aphididae) and Gynaikothrips ficorum Marchal (Thysanoptera: Ploeothridae). The EO was extracted by hydrodistillation and the bioassay was evaluated by toxicity contact method, using solutions at different concentrations and for different time intervals. The $\mathrm{EO}$ was more toxic to $G$. ficorum $\left(\mathrm{LC}_{50}=0.031 \mu \mathrm{L} \mathrm{cm}^{-2}\right)$ than $A$. nerii $\left(\mathrm{LC}_{50}=0.099 \mu \mathrm{L} \mathrm{cm}^{-2}\right)$ on filter discs at $12 \mathrm{~h}$ of exposure. These results suggested that $\mathrm{EO}$ from E. globulus constitute a good alternative for the control of $A$. nerii and $G$. ficorum, considering their insecticidal effects at low applied concentrations and for short periods of time.
\end{abstract}

Keywords: secondary metabolites, thrips, aphids, Eucalyptus globulus.

Russo, S., Yaber Grass, M. A., Fontana, H. C. y Leonelli, E. 2018. Actividad insecticida del aceite esencial de Eucalyptus globulus sobre Aphis nerii (Boyer) y Gynaikothrips ficorum (Marchal). Agriscientia 35: 63-67

\section{RESUMEN}

Los áfidos y trips son dos de las más importantes especies de plagas que invaden invernaderos y cultivos en el mundo. En los últimos años se han realizado muchos esfuerzos con el propósito de identificar plantas por sus propiedades insecticidas, como una alternativa al uso indiscriminado de insecticidas químicos que constituyen un riesgo para la salud humana y el medioambiente. El objetivo de este trabajo fue evaluar el efecto insecticida del aceite esencial (AE) de Eucalyptus globulus Labill sobre Aphis nerii Boyer de Fonscolombe (Hemiptera: Aphididae) y Gynaikothrips ficorum Marchal (Thysanoptera: Ploeothridae). El AE se extrajo por hidrodestilación y 
los bioensayos se evaluaron usando el método de toxicidad por contacto a diferentes concentraciones e intervalos de tiempo. Estudios exploratorios se realizaron previamente para determinar las concentraciones apropiadas de testeo. El AE fue más tóxico sobre $G$. ficorum $\left(\mathrm{LC}_{50}=0.031 \mu \mathrm{L} \mathrm{cm} \mathrm{cm}^{-2}\right)$ que sobre A. nerii $\left(\mathrm{LC}_{50}=0.099 \mu \mathrm{L} \mathrm{cm}^{-2}\right)$ en el ensayo realizado en discos de papel de filtro correspondiente a las $12 \mathrm{~h}$ de exposición. Estos resultados sugieren que el $\mathrm{AE}$ de E. globulus constituye una buena alternativa para el control de A. nerii y $G$. ficorum considerando el efecto insecticida a bajas concentraciones y cortos tiempos de exposición.

Palabras clave: metabolitos secundarios, trips, áfidos, Eucalyptus globulus.

Russo, S., Yaber Grass, M. A., Fontana, H. C. and Leonelli, E.: Universidad de Buenos Aires, Facultad de Agronomía. Avenida San Martín 4453, 1417, Ciudad Autónoma de Buenos Aires, Argentina. Correspondence to: srusso@agro.uba.ar

\section{INTRODUCTION}

The recent migrations from villages to urban cities have resulted in an increase of the number of green spaces for the family recreation and frequently we can encounter species of ornamental plants cultivated in them. Several harmful factors damage plants and one of the most important is the presence of insects (Kaplanski and Venier, 2012).

This study focuses on Aphis nerii Boyer de Fonscolombe (Hemiptera: Aphididae) and Gynaikothrips ficorum (Marchal) (Thysanoptera: Ploeothridae). This aphid is one of the common pests of several important ornamental plants, its host range includes several genera of Asclepiadaceae such as Morrenia, Asclepias curassavica L, Ceropegia woodii Schltr. and Apocynaceae (Nerium and Vinca) (Mohammad, Mohammad and Salma, 2012). As regards the thrip under study, it comprises approximately 40 species of dark brown to black thrips which induce galls on developing leaf tissues of Ficus species (Rosales: Moraceae) (Dang, Mound and Qiao, 2014). Ficus spp. is one of the most common and widespread tropical genus in the modem era. Especially, Ficus benjamina L., these ornamental and urban trees, are widely disseminated in several countries and especially in Argentina (Frodin, 2004; De Borbón and Agostini, 2011).

Aphids and thrips are serious pests and vectors that transmit viruses to field crops, vegetables, ornamentals, and greenhouse crops. They have displayed a remarkable ability to develop resistance to almost every insecticide with which they have been treated (Arthurs, Guixin Chen and Chen, 2016).

Eucalyptus globulus (Myrtaceae) is commonly grown in central areas of Argentina, its leaves contain compounds such as $\alpha$-pinene and $\beta$-pinene, globulol, terpineol, and specially 1,8-cineole, the most predominant monoterpene (Lucia, Licastro, Zerba, Audino and Masuh, 2009). These secondary metabolites demonstrated insecticidal and repellent properties against pests in stored grains (Russo, Cabrera, Chludil, Yaber Grass and Leicach, 2015).

The application of chemical pesticides and fumigants is the most economical and common practice used but it has disadvantages that have been reported in several countries. They have reported the development of insect strains resistant to pesticides, the presence of residues toxic for human consumption, acute and chronic toxicity for workers and adverse effects on the environment. (Elumalai, Krishnappa, Anandan, Govindarajan and Mathivanan, 2010; Boyer, Zhang and Lempèriere, 2012). Studies indicate that plant secondary metabolites, may affect significantly the plant resistance to parasites and microorganisms (Pérez-Urria Carril and Ávalos García, 2009; Sepúlveda Jiménez, Porta-Ducoing and RochaSosa, 2004).

Taking into account this situation, botanical insecticides are a sustainable alternative to integrated pest management that could contribute to reducing the use of synthetic insecticides. This work reports on E. globulus EO insecticidal activity against $A$. nerii and $G$. ficorum adults.

\section{MATERIAL AND METHODS}

\section{Essential Oil Extraction}

Fresh mature leaves of E. globulus were collected from plants cultivated in Lobería, Buenos 
Aires, Argentina ( $38^{\circ} 9^{\prime} 48^{\prime \prime} \mathrm{S}, 58^{\circ} 46^{\prime} 53^{\prime \prime} \mathrm{W}$ ). The EO was extracted from freshly collected leaves $(150 \mathrm{~g})$ by hydrodistillation using a modified Clevenger-type apparatus for $2 \mathrm{~h}$ and stored at $-18^{\circ} \mathrm{C}$. Essential oil content was calculated for each repetition $(n=4)$ and expressed as a percentage (v/w, fresh weight). Phytochemical data analyses were performed by gas chromatography (GC) and gas chromatography-mass spectrometry (GC-MS) and were reported in a previous work (Russo et al., 2015).

\section{Insecticidal activity bioassay}

Experiments were performed in the Laboratory of Agricultural Zoology (Agronomy School, University of Buenos Aires). Aphis nerii and Gynaikothrips ficorum adult insects were collected in the campus of the Agronomy School. The insects used for bioassays were taken directly from the field and they have not been reared in the laboratory because of the reduced information about nutritional factors, and climatic requirements of the species biological cycle. The insecticidal activity of E. globulus EO was evaluated by contact method conducted using filter paper discs (Whatman $\mathrm{n}^{\circ}$ 1, 9-cm diameter pieces). Range-finding studies were run to determine the appropriate testing concentrations for each insect. EO samples were dissolved in acetone and applied on the surface of the paper in an amount equal to $0,0.05,0.10,0.15$ and $0.20 \mu \mathrm{L} \mathrm{cm}^{-2}$ for $A$. nerii and $0,0.10,0.15,0.20$ and $0.25 \mu \mathrm{L} \mathrm{cm}^{-2}$ for $G$. ficorum. After 10 min when the solvent had evaporated, 10 adult aphids and thrips were deposited into each glass Petri dish. Four replicates were made for each treatment and a control using acetone. Mortality percentages were determined after $0.5,2,4,6,12$, 24 and 48 h-insects were considered dead when, prodded with a fine brush (maximum three times), they showed no appendage movement. Mortality was determined by the percentage of dead insects after the time of exposure to EO concentration. Percent mortality values were computed using the formula: $M(\%)=(n / N) \times 100$; where: $n=$ the number of dead insects, and $\mathrm{N}=$ the number of insects on treated discs. Mortality data were subjected to probit analysis to determine the lethal concentration $50\left(\mathrm{LC}_{50}\right)$ values (with 95\% confidence limits).

\section{Statistical analysis}

Statistical methods were employed using InfoStat/Professional software version $1.1 \quad$ (Di Rienzo et. al, 2002). Tests of normality (KolmogorovSmirnov test) and homogeneity of variance (Levene test) were applied in each analysis. Mortality and EO concentration over the analyzed periods were performed using two-way ANOVA, and differences between means were compared to the control using Tukey's test with a 0.05 confidence interval in a completely randomized design. Different capital letters indicate significant differences between values in the same row, and different small letters indicate significant differences between values in the same column. To estimate $\mathrm{LC}_{50}$ values, mortality data were subjected to Probit analysis (Finney, 1971, 2nd edition). Results from each program were pooled and statistical analysis conducted to find regression equation ( $\mathrm{Y}=$ mortality; $\mathrm{X}=$ concentrations), using GraphPad Prism 6.01 (GraphPad Software, 2012).

\section{RESULTS AND DISCUSSION}

The toxicity bioassay indicated that EO showed insecticidal properties against $A$. nerii adults (Table 1). After $30 \mathrm{~min}$ of exposure, the treatment with $0.20 \mu \mathrm{L} \mathrm{cm} \mathrm{cm}^{-2} \mathrm{EO}$ against $A$. nerii presented $35 \%$ of dead adults, which is the highest value for this time of exposure. The same mortality rate was observed for the lowest assayed concentration $\left(0.05 \mu \mathrm{L} \mathrm{cm}^{-2}\right)$ but only at $24 \mathrm{~h}$. The two EO treatments with the

Table 1. Concentrations, exposure time and mortality of essential oil from Eucalyptus globulus in adult Aphis nerii

\begin{tabular}{|c|c|c|c|c|c|}
\hline & Control & $0.05 \mu \mathrm{L} \mathrm{cm}^{-2}$ & $0.10 \mu \mathrm{L} \mathrm{cm}{ }^{-2}$ & $0.15 \mu \mathrm{L} \mathrm{cm}^{-2}$ & $0.20 \mu \mathrm{L} \mathrm{cm}^{-2}$ \\
\hline$M(0.5 \mathrm{~h})$ & OA & OAa & OAa & $7.50 \pm 1.52 \mathbf{A b}$ & $35.00 \pm 5.77 \mathrm{Eg}$ \\
\hline M (2 h) & OA & $7.50 \pm 2.50 \mathbf{A b}$ & $7.50 \pm 2.00 \mathbf{A b}$ & $10.00 \pm 1.16 \mathbf{A b c}$ & $40.00 \pm 8.16 \mathrm{Eh}$ \\
\hline M (4 h) & OA & $7.50 \pm 2.50 \mathbf{A b}$ & $10.00 \pm 1.16$ Abc & $20.00 \pm 2.16 \mathbf{A e}$ & $60.00 \pm 8.16 \mathrm{Hi}$ \\
\hline$M(6 h)$ & OA & $7.50 \pm 2.50 \mathbf{A b}$ & $12.50 \pm 1.57 \mathrm{~A}-\mathrm{d}$ & $32.50 \pm 2.15 \mathrm{Dg}$ & $87.50 \pm 12.58 \mathrm{~J}-\mathbf{I}$ \\
\hline$M(12 \mathrm{~h})$ & OA & $30.00 \pm 2.16 \mathbf{B}-\mathbf{g}$ & $32.5 \pm 2.57$ B-f & $77.50 \pm 3.50 \mathbf{l j k}$ & $95.00 \pm 10 \mathrm{KI}$ \\
\hline M (24 h) & $\mathrm{OA}$ & $32.50 \pm 2.57 \mathrm{D}-\mathrm{g}$ & $45.00 \pm 4.77 \mathrm{Gh}$ & $95.00 \pm 5.77 \mathbf{K k}$ & $100.00 \pm 0.00 \mathrm{LI}$ \\
\hline$M(48 h)$ & OA & $42.50 \pm 3.50 F-h$ & $72.50 \pm 5.57 \mathbf{l j}$ & $100.00 \pm 0.00 \mathrm{LI}$ & $100.00 \pm 0.00 \mathrm{LI}$ \\
\hline
\end{tabular}

M: adult mortality mean values $(\%, n=4)$. Different letters indicate significant differences verified by ANOVA two-way and Tukey's test $(\mathrm{P}<0.05)$ Capital letters represent comparisons between the applied concentrations (in columns rows), and lower case letters represent comparisons between the observation times (in rows columns). 
highest concentrations $\left(0.15\right.$ and $\left.0.20 \mu \mathrm{L} \mathrm{cm} \mathrm{cm}^{-2}\right)$ exhibited the death of all insects when the exposure time was 48 and $24 \mathrm{~h}$, respectively.

The results suggested that, at $24 \mathrm{~h}$ of exposure, EO applied at $0.15 \mu \mathrm{L} \mathrm{cm}^{-2}$ presented effective activity with values under $100 \%$ (95\%) up to $100 \%$ after $48 \mathrm{~h}$.

Eucalyptus $\mathrm{EO}$ at the lowest tested concentration $\left(0.10 \mu \mathrm{L} \mathrm{cm}^{-2}\right)$ against adult $\mathrm{G}$. ficorum (Table 2) had noticeable insecticidal effects because the mortality achieved was of 55\% in $6 \mathrm{~h}$ and $100 \%$ at the end of experiment. EO at $0.15 \mu \mathrm{L} \mathrm{cm}{ }^{-2}$ achieved the maximum lethal effect when the bioassay was concluded (24 h).

After recalculating statistical significance between the different applied concentrations for each exposure time, we observed that at $12 \mathrm{~h}$ all EO solutions showed the most significant differences with respect to the control (Tables 1 and 2). At this time, the highest concentrations $\left(0.25 \mu \mathrm{L} \mathrm{cm}^{-2}\right)$ achieved $100 \%$ of mortality. In view of the above, mortality data at $12 \mathrm{~h}$ were subjected to probit analysis to determine the lethal concentration $50\left(\mathrm{LC}_{50}\right)$ values (with 95\% confidence limits). From the probit analyses, the calculated regression line equation was $Y=25,02^{*} X+2,515$ and $Y=11,74^{*} X+4,628$ for $A$. nerii and $G$. ficorum respectively. According to these results, $G$. ficorum adults $\left(\mathrm{LC}_{50}=0.031\right.$ $\pm 0.01 \mu \mathrm{L} \mathrm{cm}^{-2}$ ) were more sensitive than $A$. nerii adults $\left(\mathrm{LC}_{50}=0.099 \pm 0.01 \mu \mathrm{L} \mathrm{cm}^{-2}\right)$ to E. globulus EO.

Similar observations were found by RegnaultRoger, Philogene and Vincent (2004) and Russo et al. (2015). They demonstrated that E. globulus EO had insecticidal effects against adult insects of stored grains: Acanthoscelides obtectus (Coleoptera: Bruchidae) and Tribolium confusum (Coleoptera: Tenebrionidae). Additionally, Mareggiani, Russo and Rocca (2008) and Castresan, Rosenbaum and González (2013) reported changes of behavior patterns and lethal effects in A. gossypii and Macrosiphum euphorbiae aphids when they were treated with E. globulus EO. Several investigations were carried out on the insecticidal effects of $E$. globulus EO against different insects (Russo et al., 2015; Kumar, Mishra, Malik and Satya, 2012). The bioassay carried out by Mossi et al. (2011) also demonstrated insecticidal activity of $E$. globulus EO against $S$. zeamais, the major pest of maize. They carried out the assay on filter paper and informed that EO caused $100 \%$ mortality after $24 \mathrm{~h}$ of exposure at concentrations equal to $0.16 \mu \mathrm{L} \mathrm{cm}^{-2}$ and a $\mathrm{LC}_{50}$ value of $0.10 \mu \mathrm{L} \mathrm{cm}^{-2}$.

These results suggest that E. globulus EO has effective insecticidal activity in a concentration of $0.15 \mu \mathrm{L} \mathrm{cm}^{-2}$ against $A$. nerii and G. ficorum, because the mortality percentage of adults reached 95\% after 24 and 12 hours of exposure time, respectively. EO from E. globulus constitutes a good alternative to the control of $A$. nerii and $G$. ficorum, considering its insecticidal effects at low applied concentrations and short exposure times. However, this preliminary laboratory investigation could represent the basis for further field research on the efficacy and the viability of the application of this EO against aphids and thrips.

\section{CONCLUSIONS}

In conclusion, E. globulus EO had valuable bioinsecticidal effects at low concentrations and short exposure times against $A$. nerii and $G$. ficorum. In the context of integrated pest management, due to its low toxicity, rapid degradation in the environment and efficiency in pest control, it provides a friendly alternative to chemical insecticides.

\section{REFERENCES}

Arthurs, S. P., Guixin Chen, G. and Chen J. (2016) Host specificity evaluation for Gynaikothrips uzeli (Thysanoptera: Phlaeothripidae) on ornamental Ficus (Rosales: Moraceae). Florida Entomologist, 99 (3), 481-486.

Table 2. Concentrations, exposure time and mortality of essential oil from Eucalyptus globulus in Gynaikothrips ficorum

\begin{tabular}{|c|c|c|c|c|c|}
\hline & Control & $0.10 \mu \mathrm{L} \mathrm{cm}^{-2}$ & $0.15 \mu \mathrm{L} \mathrm{cm}^{-2}$ & $0.20 \mu \mathrm{L} \mathrm{cm}^{-2}$ & $0.25 \mu \mathrm{L} \mathrm{cm}^{-2}$ \\
\hline$M(0.5 \mathrm{~h})$ & OA & OA & $10.00 \pm 0.00 \mathbf{A b}$ & $20.00 \pm 14.14 \mathbf{A c}$ & $22.50 \pm 2.00 B c$ \\
\hline$M(2 \mathrm{~h})$ & $O A$ & $25.00 \pm 2.77 \mathbf{B c}$ & $25.00 \pm 1.77 \mathrm{Bc}$ & $30.00 \pm 2.16 \mathbf{C d}$ & $50.00 \pm 1.50 \mathbf{E}$ \\
\hline$M(4 h)$ & $\mathrm{OA}$ & $45.00 \pm 2.77 \mathbf{D e}$ & $47.50 \pm 2.57 \mathbf{E}$ & $60.00 \pm 3.50 \mathrm{E}$ & $92.50 \pm 2.57 \mathbf{F g}$ \\
\hline$M(6 h)$ & OA & $55.00 \pm 2.77 \mathbf{E}$ & $80.00 \pm 0.00 F$ & $85.00 \pm 3.77 \mathbf{F g}$ & $97.50 \pm 3.00 \mathbf{G}$ \\
\hline$M(12 h)$ & OA & $90.00 \pm 0.00 \mathbf{F g}$ & $95.00 \pm 3.77 \mathbf{F g}$ & $95.00 \pm 2.00 \mathrm{Fg}$ & $100.00 \pm 0.00 \mathbf{G}$ \\
\hline M (24 h) & OA & $100.00 \pm 0.00 \mathbf{G}$ & $100.00 \pm 0.00 \mathbf{G}$ & $100.00 \pm 0.00 \mathbf{G}$ & $100.00 \pm 0.00 \mathbf{G}$ \\
\hline
\end{tabular}

M: adult mortality mean values $(\%, n=4)$. Different letters indicate significant differences verified by ANOVA two-way and Tukey's test $(\mathrm{P}<0.05)$ Capital letters represent comparisons between the applied concentrations (in columns rows), and lower case letters represent comparisons between the observation times (in rows columns) 
Boyer, S., Zhang H. and Lempérière, G. (2012). A review of control methods and resistance mechanisms in stored-product insects. Bulletin of Entomological Research, 102, 213-229.

Castresan, J. E., Rosenbaum, J. and González, L. A. (2013). Estudio de la efectividad de tres aceites esenciales para el control de áfidos en pimiento, Capsicum annuum L. Idesia, 31 (3), 49-58.

Dang, L. H., Mound, L. A. and Qiao, G. X. (2014). Conspectus of the Phlaeothripinae genera from China and Southeast Asia (Thysanoptera, Phlaeothripidae). Zootaxa, 3807, 1-82.

De Borbón, C. M. and Agostini, J. P. (2011). Gynaikothrips uzeli (Zimmermann) y Androthrips ramachandrai Karny (Thysanoptera, Phlaeothripidae), primeras citas para la Argentina. Revista de la Facultad de Ciencias Agrarias. Universidad Nacional de Cuyo, 43 (1), 253260.

Di Rienzo, J. A., Casanoves F., Balzarini M.G., Gonzalez L., Tablada M. and Robledo C.W. InfoStat versión 2002. Grupo InfoStat, FCA, Universidad Nacional de Córdoba, Argentina. URL http://www.infostat.com.ar

Elumalai, K., Krishnappa, K., Anandan, A., Govindarajan, M. and Mathivanan, T. (2010). Antifeedant activity of medicinal plant essential oils against Spodoptera litura (Lepidoptera: Noctuidae). International Journal of Recent Scientific Research, 2, 62-68.

Finney D. J. (1971). Probit Analysis (third ed.), Cambridge, United Kingdom: Cambridge University Press.

Frodin, D. G. (2004). History and concepts of big plant genera. Taxon, 53 (3), 753-776.

GraphPad Prism (version 6.01) [Analysis, Statistics and Graphing Software] (2012). San Diego, California, United States: GraphPad Software.

Kaplanski, M. and Venier, J. A. (2012). Caracteres ornamentales de árboles y arbustos. Unpublished manuscript, Cátedra de Jardinería, Facultad de Agronomía, Universidad de Buenos Aires.

Kumar, P., Mishra, S., Malik, A. and Satya, S. (2012). Compositional analysis and insecticidal activity of Eucalyptus globulus (family: Myrtaceae) essential oil against housefly (Musca domestica). Acta Tropica, 122, 212-218.

Lucia, A., Licastro, S., Zerba, E, Audino, P. G. and Masuh, H. (2009). Sensitivity of Aedes aegypti adults (Diptera: Culicidae) to the vapors of Eucalyptus essential oils. Bioresource Technology, 100 (23), 6083-6087.

Mareggiani, G., Russo, S. and Rocca, M. (2008). Eucalyptus globulus (Mirtaceae) essential oil: efficacy against Aphis gossypii (Hemiptera: Aphididae), an agricultural pest. Revista Latinoamericana de Química, 36, 16 - 21.

Mohammad, R., Mohammad, A. S. and Salma, K. (2012). Insecticidal effect of silver and zinc nanoparticles against Aphis nerii Boyer of fonscolombe (Hemiptera: Aphididae). Chilean Journal Agricultural Research, 72 (4), 590-594.

Mossi, A. J., Astolfi, V., Kubiak, G., Lerin, L., Zanella, C., Toniazzo, G., Oliveira, D., Treichel, H., Devilla, I. A., Cansiana, R. and Restello, R. (2011). Insecticidal and repellency activity of essential oil of Eucalyptus sp. against Sitophilus zeamais Motschulsky (Coleoptera, Curculionidae). Journal of the Science of Food and Agriculture, 91, 273-277.

Pérez-Urria Carril, E. and Ávalos García, A. (2009). Metabolismo secundario de plantas. Revista Reduca (Serie Biología), 2 (3), 119-145.

Regnault-Roger, C., Philogène, B. J. y Vincent, C. (2004). Biopesticidas de Origen Vegetal. Madrid, España: Ediciones Mundi-Prensa.

Russo, S., Cabrera, N., Chludil, H. D., Yaber Grass, M. A. and Leicach, S. R. (2015). Insecticidal activity of young and mature leaves essential oil from Eucalyptus globulus Labill. against Tribolium confusum Jacquelin du Val (Coleoptera: Tenebrionidae). Chilean Journal Agricultural Research, 75 (3), 375-379.

Sepúlveda-Jiménez, G., Porta-Ducoing, H., RochaSosa, M. (2004). La participación de los metabolitos secundarios en la defensa de las plantas. Revista Mexicana de Fitopatología, 21, 355-363. 